\title{
ALTERATION OF BODY COMPOSITION IN RATS: EFFECT OF ORGANIC CHROMIUM AND L-CARNITINE
}

\author{
S. FEKETE ${ }^{1 *}$, I. SZAKÁLL ${ }^{1}$, Emma Kósa $^{1}$, Emese ANDRÁSOFSZKY ${ }^{1}$, Kinga FOdOR ${ }^{1}$, \\ A. $\operatorname{HIDAS}^{2}$ and J. TÖZSÉR ${ }^{3}$ \\ ${ }^{1}$ Szent István University, Faculty of Veterinary Science Budapest, H-1400 Budapest, \\ P.O. Box 2, Hungary; ${ }^{2}$ Institute for Small Animal Research, Gödöllő, Hungary; \\ ${ }^{3}$ Szent István University, Faculty of Agricultural Science, Gödöllő, Hungary
}

(Received July 31, 2000; accepted May 17, 2001)

\begin{abstract}
A growth trial was carried out to test the effect of organic, trivalent chromium and L-carnitine on the body composition of growing rats. At the same time, an evaluation of different measurement methods (weight of epididymal fat pad, adipocyte morphometry, total body electrical conductivity) was performed. Outbred Wistar rats of 30 days of age were fed diets of different (0,10 and 20\%) protein level. The diets were supplemented with $4 \mathrm{mg} / \mathrm{kg} \mathrm{Cr}$ as chromium nicotinate, and $100 \mathrm{mg} / \mathrm{kg} \mathrm{L}$-carnitine. The experimental feeding lasted 15 days, after a 5-day-long adjustment period. It was found that $\mathrm{Cr}$ addition increased feed intake. Both treatments caused changes in body composition, increasing fat and protein deposition. Organic chromium had no effect at either protein level, while Lcarnitine improved the protein retention only at an optimum (20\%) protein supply. No statistically significant correlation was found between total body electrical conductivity (TOBEC) and body composition, which could be attributed to the great individual differences. A close correlation was found among total body fat percentage, weight of epididymal fat pad and the adipocyte surface. The data suggest that there is an interaction between dietary protein supply and the effect of repartitioning agents.
\end{abstract}

Key words: Trivalent chromium, L-carnitine, body composition, protein efficiency ratio (PER), net protein ratio (NPR), rat, dietary protein level, adipocyte morphometry, epididymal fat pad, total body electrical conductivity (TOBEC), nutriceuticals

It is widely accepted that some nutriceuticals like organic chromium (chromium picolinate or nicotinate) and L-carnitine increase the tissue retention of protein and/or fat (Borum, 1983; Mowat, 1997). Both production trials (Tilley, 1995; Janssen and De Wilde, 1995; Gálvez et al., 1996; Fekete and Kósa, 1999; Fekete et al., 1999; Kósa and Fekete, 1999) and basic research have provided such evidence. However, some data are contradictory (Owen et al., 1993; Barker and Sell, 1994; Clouet et al., 1996) and there are few really controlled test (Rabie

*Corresponding author; E-mail: safekete@univet.hu; Fax: +36 (1) 478-4128 
and Szilágyi, 1998). One of the uncertainties may be caused by the interaction of diet composition, repartitioning agent and body composition (Guggenbuhl, 1996; Hemel-Grooten et al., 1998).

There is an increasing need both in human medicine and in animal science for non-invasive methods of measurement of total body composition in vivo. Indirect methods for the determination of body composition give estimates of varying precision for major chemical components. This is especially true for the determination of body fat content of a given individual. There is some evidence that the distribution (anatomical site) of fat in the body is a better indicator of the condition than total body fat (Robelin and Casteilla, 1990). The concept of adipocyte cellularity helps to explain the earlier, sometimes contradictory observations. This means that during fat deposition or mobilisation young growing animals show changes in fat cell number and size, whereas in older individuals changes occur only in cell size (Hirsch and Han, 1969; Hirsch and Knittle, 1970). There is a linear relationship between adipose cell volume and total fat content. This holds health concerns too, because larger adipocytes produce more leptin, a well-known satiety signal (Houseknecht et al., 1998), but at the same time they are less sensitive to insulin than smaller cells. Hirsch and Gallian (1968) evaluated different procedures for adipose cell measurement. The osmium tetroxide fixation method proved to be more accurate in comparison with other procedures on different species. Smith et al. (1984) used adipose tissue biopsy and deuterium oxide dilution technique to detect changes in body composition of growing steers. The data of this study provide strong evidence that in vitro measurements of adipose tissue lipogenic enzyme activities are indicative of increased gain of body fat in cattle.

Scoring systems can be used only in species in which large amounts of fat are deposited subcutaneously, like in cows (Fekete et al., 1996a). Therefore, it is clear that finding a reliable fat store is essential in adipocyte techniques. In rats, this fat store can be the epididymal fat pad, which is well defined and easy to find. It seems that the amount of this fat pad changes parallel to the body composition of the animal. Sainz and Wolff (1988) found that the subcutaneous adipose tissue of Sprague-Dawley rats appeared to be more sensitive than abdominal fat to cimaterol treatment.

Total body electrical conductivity (TOBEC) is recommended for serial estimations of body composition in animals and man (Forbes, 1987). The TOBEC technique relies on the difference in electrical conductivity and dielectric properties between fat-free mass (FFM; which actually contains all the water and conducting electrolytes) and fat mass. This method was demonstrated to predict accurately the FFM and the total body water (TBW) in different species of animals and in humans (Fekete, 1992). Fiorotto et al. (1987) found that the accuracy of TOBEC measurement in pigs can be improved by taking into account individual variability in shape as indicated by the weight/length ${ }^{2}$ index. However, 
in case of rats from the same strain this does not influence the measurement. Trocki et al. (1995) studied the precision of the TOBEC technique in predicting body composition of a population of adult male rats that had undergone 7 treatments, including adrenalectomy and blocking of glucocorticoid receptors, in an experiment on the aetiology of obesity. Measurements underestimated lean body mass and reciprocally overestimated fat content. To improve accuracy and reliability of the TOBEC technique, a prediction equation should be developed from the same population, and experimental group sizes should be relatively large. Bell et al. (1994) concluded that TOBEC could not be used instead of carcass analysis for the accurate prediction of the body composition of rats during or following the administration of a variety of experimental treatments. Stenger and Bielajew (1995) compared total body electrical conductivity (TOBEC) predictions of overall body fat to combined perirenal and epididymal fat pad weight. The latter are considered reasonable estimates of overall adiposity. Kósa et al. (1997) improved the accuracy of measurement by using a previous 12-h feed and water deprivation period and appropriate analgesia in dwarf rabbits.

A short-term experiment was carried out by Szakáll et al. (2000) to test the effect of inorganic chromium, manganese and DL-carnitine on body composition of growing rats. Outbred Wistar rats of 6-7 weeks of age were used. The purified diets were balanced for all minerals except $\mathrm{Cr}$ and $\mathrm{Mn}$, which were decreased in the control diet ( 0.86 and $69.74 \mathrm{mg} / \mathrm{kg} \mathrm{Cr}$ and $\mathrm{Mn}$, respectively) to get better additional effect. The following types of supplementation were used: $1500 \mathrm{mg} / \mathrm{kg}$ $\mathrm{Cr}$ as $\mathrm{CrCl}_{3}, 500 \mathrm{mg} / \mathrm{kg} \mathrm{Mn}$ as $\mathrm{MnSO}_{4}$ and $1000 \mathrm{mg} / \mathrm{kg}$ DL-carnitine. The experimental feeding lasted 14 days, after a 13-day long adjustment period. $\mathrm{Cr}$ and Mn addition slightly decreased food intake. Although the body composition of $\mathrm{Cr}$-fed rats tended to get fatter, statistically there was no difference $(\mathrm{p}>0.1)$ in body composition between the different treatment groups. Data suggest the small or zero effect of inorganic chromium, manganese and DL-carnitine supplementation on body composition of growing rats.

The primary objective of the present study was to determine the effect of supplementation with repartitioning agents (organic chromium and L-carnitine) at two different dietary protein levels on protein utilisation and body composition of growing rats. In addition, the accuracy of two indirect methods, i.e. the adipocyte cell measurement and TOBEC, was evaluated.

\section{Materials and methods}

Animals

SPF (FELESA) weaned male Wistar rats of 30 days of age, obtained from the Central Animal House of the Semmelweis Medical University of Budapest, were used. The animals were housed in the conventional animal facility of the 
Institute of Animal Breeding, Nutrition and Laboratory Animal Science of the Faculty of Veterinary Science, Szent István University in groups of six rats each. They were kept at $28 \pm 1{ }^{\circ} \mathrm{C}$ room temperature, $65 \%$ relative humidity, and a light/dark cycle of 14/10 h. A 5-day accommodation period was used, during which an adjustment diet (Table 1) was fed ad libitum. On Day 0, new groups of 6 rats each were randomly formed with the help of the Microsoft Excel programme to obtain the similar average liveweights and the equal-and-least variance (Kovalcsik, 1996). The animals were housed in wire mesh cages to avoid caecotrophy. The feeding box was placed inside the cage, which allowed measuring the feed intake and minimised feed loss. The rats were fed the test diets ad libitum. The physical form of all diets was powder to avoid spilling. Drinking tap water was offered in glass bottles re-filled daily. The length of the experiment was 15 days. The rats were weighed on Days 2, 4, 7, 10 and 15.

Table 1

Composition of adjustment and protein-free diets, gram $/ \mathrm{kg}$

\begin{tabular}{lcc}
\hline \multicolumn{1}{c}{ Ingredients } & Adjustment diet & Protein-free diet \\
\hline Soybean meal (equal to $15 \% \mathrm{CP}^{* *}$ ) & 326.10 & - \\
D-glucose & - & 150.00 \\
Premix & 50.00 & 50.00 \\
Sunflower oil & 7.50 & 7.50 \\
Lard & 92.50 & 142.50 \\
Cellulose powder & 50.00 & 50.00 \\
Corn starch (ad 100\%) & 474.40 & 600.00 \\
\hline
\end{tabular}

${ }^{*}$ composition of premix in Table $3 ;{ }^{* *} \mathrm{CP}=$ crude protein

\section{Raw materials}

Soybean meal was purchased from Rákosmezeje Co. Ltd. Potato and maize starch came from Szabadegyháza Distillery Co. Ltd. Pig lard and sunflower oil are human commercial products. The cellulose powder originated from Reanal Ltd. The premix was made at the Feed Mixing Plant of Bábolna Ltd. with maize starch carrier. 


\section{Experimental diets}

Both repartitioning agents were used at 10 and $20 \%$ crude protein level. The protein source was solvent-extracted soybean meal. The dietary level of chromium nicotinate was $4 \mathrm{mg} / \mathrm{kg}$, while that of L-carnitine was $100 \mathrm{mg} / \mathrm{kg}$. The basal (control) diet contained no protein (Table 1), to allow the calculation of Net Protein Ratio (NPR). The treatments and the symbols used later are shown in Table 2. Natural composition of the semi-purified experimental diet is given in Table 3 .

Table 2

Treatments and symbols

\begin{tabular}{ll}
\hline \multicolumn{1}{c}{ Symbol } & \multicolumn{1}{c}{ Treatment } \\
\hline PFD & Protein-free diet \\
$10 \mathrm{CP}$ & Basal diet with $10 \% \mathrm{CP}$ \\
$20 \mathrm{CP}$ & Basal diet with $20 \% \mathrm{CP}$ \\
$10 \mathrm{CP}+\mathrm{Cr}$ & Basal diet with $10 \% \mathrm{CP}+\mathrm{Cr}$ nicotinate \\
$20 \mathrm{CP}+\mathrm{Cr}$ & Basal diet with $20 \% \mathrm{CP}+\mathrm{Cr}$ nicotinate \\
$10 \mathrm{CP}+\mathrm{CARN}$ & Basal diet with $10 \% \mathrm{CP}+\mathrm{L}$-carnitine \\
$20 \mathrm{CP}+\mathrm{CARN}$ & Basal diet with $20 \% \mathrm{CP}+\mathrm{L}$-carnitine \\
\hline
\end{tabular}

Table 3

Composition of the experimental diets

\begin{tabular}{lcccccc}
\hline \multicolumn{1}{c}{ Ingredients } & $10 \mathrm{CP}^{1}$ & $10 \mathrm{CP}+\mathrm{Cr}^{2}$ & $\begin{array}{c}10 \mathrm{CP}+ \\
\mathrm{CARN}^{3}\end{array}$ & $20 \mathrm{CP}^{4}$ & $\begin{array}{r}20 \mathrm{CP}+ \\
\mathrm{Cr}^{5}\end{array}$ & $\begin{array}{c}20 \mathrm{CP}+ \\
\mathrm{CARN}^{6}\end{array}$ \\
\hline Cr nicotinate, $\mathrm{mg}$ & - & 4 & - & - & 4 & - \\
L-carnitine, $\mathrm{mg}$ & - & - & 100 & - & - & 100 \\
Soybean meal, g & 208.64 & 208.64 & 208.64 & 417.26 & 417.26 & 417.26 \\
Sunflower oil, g & 7.5 & 7.5 & 7.5 & 7.5 & 7.5 & 7.5 \\
Lard, g & 142.5 & 142.5 & 142.5 & 142.5 & 142.5 & 142.5 \\
Cellulose powder, g & 50 & 50 & 50 & 50 & 50 & 50 \\
Premix ${ }^{*}, \mathrm{~g}$ & 50 & 50 & 50 & 50 & 50 & 50 \\
Maize starch, g & & & & &
\end{tabular}

*1 kg premix contains: Vitamin A 120,000 IU/kg, Vitamin $\mathrm{D}_{3} 20,000 \mathrm{IU} / \mathrm{kg}$, Vitamin E $700 \mathrm{mg} / \mathrm{kg}$, Vitamin $\mathrm{K}_{3} 60 \mathrm{mg} / \mathrm{kg}$, Thiamine $80 \mathrm{mg} / \mathrm{kg}$, Riboflavin $60 \mathrm{mg} / \mathrm{kg}$, Nicotinic acid $800 \mathrm{mg} / \mathrm{kg}$, Capantothenate $200 \mathrm{mg} / \mathrm{kg}$, Pyridoxine $140 \mathrm{mg} / \mathrm{kg}$, Biotin $10 \mathrm{mg} / \mathrm{kg}$, Folic acid $20 \mathrm{mg} / \mathrm{kg}$, L-ascorbic acid $2000 \mathrm{mg} / \mathrm{kg}$, Choline-chloride 20,000 mg/kg, Ca $160 \mathrm{~g} / \mathrm{kg}, \mathrm{P} 120 \mathrm{~g} / \mathrm{kg}, \mathrm{Mg} 10 \mathrm{~g} / \mathrm{kg}, \mathrm{NaCl}$ $100 \mathrm{~g} / \mathrm{kg}, \mathrm{Fe} 800 \mathrm{mg} / \mathrm{kg}$, Mn $1500 \mathrm{mg} / \mathrm{kg}, \mathrm{Zn} 260 \mathrm{mg} / \mathrm{kg}$, Cu $120 \mathrm{mg} / \mathrm{kg}$, I $3 \mathrm{mg} / \mathrm{kg}$; ${ }^{1}$ basal diet with $10 \% \mathrm{CP}$ (crude protein $=\mathrm{N} \times 6.26$ ) $;{ }^{2}$ basal diet with $10 \% \mathrm{CP}+\mathrm{Cr}$ nicotinate; ${ }^{3}$ basal diet with $10 \% \mathrm{CP}+\mathrm{L}$-carnitine; ${ }^{4}$ basal diet with $20 \% \mathrm{CP} ;{ }^{5}$ basal diet with $20 \% \mathrm{CP}+\mathrm{Cr}$ nicotinate; ${ }^{6}$ basal diet with $20 \% \mathrm{CP}+\mathrm{L}$-carnitine 


\section{Procedures}

On Day 15 of the experiment (at 50 days of age) the body composition of rats was determined by the TOBEC technique. Prior to the measurement the rats were anaesthetised with intraperitoneal pentobarbital sodium injection $(20 \mathrm{mg} / \mathrm{kg}$ body weight of Nembutal inj. A.U.V.TM, Sanofi). After the TOBEC measurements, the animals were euthanised by an overdose of the same injection in deep narcosis. The epididymal fat pad was removed and weighed. The samples were washed with a two-component Sörensen solution and then stained with heated osmium tetroxide for $24 \mathrm{~h}$. Adipocyte morphometry was performed according to Hirsch and Gallian (1968) and evaluated by the use of a special image analysis software $\left(\right.$ Cytosoft $\left.^{\circledR}\right)$. Adipocyte number, size and distribution were determined later. After removing the gut and urinary bladder content, the whole bodies were deep frozen.

\section{Methods}

Empty bodies (EB) were weighed, then cut into pieces of small size and homogenised with a grinder (KERIPAR Metal Works no. 5). Protein Efficiency Ratio (PER) and Net Protein Ratio (NPR) were calculated as follows: PER = body weight gain/CP intake and NPR = (body weight gain - body weight gain of rats fed N-free basal diet)/CP intake (Hegedüs et al., 1981). Total body electrical conductivity (TOBEC) measurement followed the procedure described by the operation manual of the EM-SCAN Model SA-2 Small Research Animal Composition Analyzer (EM SCAN Inc., 1991), modified by Fekete and Brown (1993). After calibration of the instrument using the procedure recommended by the operating manual, the animals were placed on the plastic carrier in the prone position and the carrier was placed inside the measurement chamber. The body, legs and tail were kept in the same position during the procedure. TOBEC ' $\mathrm{E}$ ' value was taken as the mean of at least five consecutive measurements. All diets and whole empty body samples were analysed for dry matter (DM), ash, ether extract (EE) and crude protein, $\mathrm{CP}(\mathrm{N} \times 6.25)$ according to procedures of the Association of Official Analytical Chemists (A.O.A.C., 1980).

\section{Statistical evaluation}

Analysis of variance (ANOVA) procedures appropriate for completely randomised design (Steele and Torrie, 1980) were conducted in the trial using SPSS software. Differences among treatments were then assessed using the least significant difference calculated from the pooled standard error of mean from ANOVA. 


\section{Ethics}

This experiment was approved and supervised by the common Ethics Committee of the University of Veterinary Science Budapest and the Scientific Veterinary Chamber of Hungary.

\section{Body weight and feed intake}

\section{Results}

Changes in liveweight after feeding the experimental diets can be expressed as percentage of the initial body weight. PFD caused $22.6 \%$ weight loss, while the rats fed diets of $10 \%$ and $20 \% \mathrm{CP}$ gained $77-95 \%$ and $122-144 \%$, respectively.

Table 4 summarises data concerning feed intake, CP intake and the calculated PER and NPR values per cage. Organic chromium supplementation greatly increased feed intake at both protein levels: $13.6 \%$ at low and $1.7 \%$ at high protein level. In this respect, L-carnitine had practically no effect $(-0.2$ vs. $+0.7 \%)$. PER values are between 2.2 and 3.0, while the NPR values are between 4.9 and 8.8 .

\section{Table 4}

Performance of rats after 15 days on the test diets (based on means per cage) ${ }^{*}$

\begin{tabular}{lcccc}
\hline & $\begin{array}{c}\text { Feed intake } \\
\mathrm{g} / \text { rat }\end{array}$ & $\begin{array}{c}\text { CP intake } \\
\mathrm{g} / \text { rat }\end{array}$ & $\begin{array}{c}\text { PER } \\
\mathrm{g} / \mathrm{g}\end{array}$ & $\begin{array}{c}\text { NPR } \\
\mathrm{g} / \mathrm{g}\end{array}$ \\
\hline PFD & 47.6 & 0 & - & - \\
10CP & 106.9 & 10.7 & 2.7 & 8.7 \\
10CP+Cr- & 121.4 & 12.1 & 3.0 & 8.3 \\
10CP+CARN & 106.7 & 10.7 & 2.8 & 8.8 \\
20CP & 117.1 & 23.4 & 2.3 & 5.1 \\
20CP Cr & 119.1 & 23.8 & 2.4 & 5.1 \\
20CP+CARN & 117.9 & 23.6 & 2.2 & 4.9 \\
\hline
\end{tabular}

$\mathrm{CP}=$ crude protein $(\mathrm{N} \times 6.25) ; \mathrm{PER}=$ protein efficiency ratio; $\mathrm{NPR}=$ net protein ratio; ${ }^{*}$ cage means, no SD can be given. For symbols see Table 2

Of the data of measurements, the absolute values of the live body weight of rats on Days 0 and 15 (end of trial) are given in Table 5. Except for the PFD group, data are in the range of the normal growth curve of rats (Hirsch and Han, 1969). The differences among treatments reflect those of the relative body weight gain. The average body weight of the group fed a protein-free diet is significantly $(\mathrm{P}<0.05)$ lower than that in all the other treatments. The animals in the groups fed $20 \% \mathrm{CP}$ diets are significantly $(\mathrm{P}<0.05)$ heavier than those on $10 \% \mathrm{CP}$ diets. The best results in terms of body weight were obtained in the group fed a $20 \% \mathrm{CP}$ diet supplemented with organic chromium. 
Table 5

Initial and final body weights of rats, gram (mean $\pm \mathrm{SD})$

\begin{tabular}{lcc}
\hline & Day 0 & Day 15 \\
\hline PFD & $63.8 \pm 0.0^{\mathrm{a}}$ & $49.38 \pm 2.17^{\mathrm{b}}$ \\
$10 \mathrm{P}$ & $63.8 \pm 0.0^{\mathrm{a}}$ & $112.97 \pm 15.41^{\mathrm{c}}$ \\
$10 \mathrm{P}+\mathrm{Cr}-$ & $63.8 \pm 0.0^{\mathrm{a}}$ & $124.10 \pm 20.07^{\mathrm{d}}$ \\
$10 \mathrm{P}+\mathrm{CARN}$ & $63.9 \pm 0.0^{\mathrm{a}}$ & $113.90 \pm 13.84^{\mathrm{c}}$ \\
$20 \mathrm{P}$ & $63.8 \pm 0.0^{\mathrm{a}}$ & $150.30 \pm 6.60^{\mathrm{e}}$ \\
$20 \mathrm{P} \mathrm{Cr}-$ & $63.8 \pm 0.0^{\mathrm{a}}$ & $155.38 \pm 9.33^{\mathrm{e}}$ \\
$20 \mathrm{P}+\mathrm{CARN}$ & $63.8 \pm 0.0^{\mathrm{a}}$ & $143.97 \pm 12.24^{\mathrm{e}}$ \\
\hline
\end{tabular}

Values in a column with different letters in superscript (a, b, c, d, e) are significantly different at $\mathrm{P}<0.05$. For symbols see Table 2

Table 6 gives the empty body weight (EBW), i.e. the carcass without the epididymal fat pad, blood, gut and urinary bladder content. The major chemical components (DM, ash, EE, and CP) are expressed as a percentage of the wet EBW. Both protein level and supplementation changed the total body composition, especially the fat (EE) content. The fat content of the groups fed $20 \% \mathrm{CP}$ diets is significantly lower (8.00-9.90\%) than that of animals receiving diets of $10 \% \mathrm{CP}$ content $(11.93-15.77 \%)$. There are no significant differences $(\mathrm{P}<0.05)$ among treatments (organic chromium or L-carnitine supplementation) in case of diets of $10 \% \mathrm{CP}$ content. The protein content of animals fed $20 \% \mathrm{CP}$ diets is higher, but the differences are not statistically significant $(\mathrm{P}>0.05)$. There is no significant $(\mathrm{P}>0.05)$ difference among treatments in the crude protein concentrations of the body of rats fed $20 \%$ CP diets.

Figure 1 shows the major chemical components of the dry matter content of whole bodies.

Data of the methods to be evaluated are compared in Table 7. The mass of the epididymal fat pad is given in grams, the estimated surface of a typical adipocyte from the epididymal fat pad of each treatment in $\mu \mathrm{m}^{2}$, and the total body electrical conductivity number, the ' $\mathrm{E}$ ' value is also indicated. Groups show the same tendencies as in the chemical analysis, but the great variance is striking. Significant differences $(\mathrm{P}<0.05)$ can be found only between the values of animals on proteinfree diet and those on 10 or $20 \% \mathrm{CP}$. Table 8 gives a comparison of the produced total fat and protein per rat in the test phase (the gross amount of EBW of an average individual per treatment), to see the cumulative effects. The calculated adipocyte diameters are also given (we supposed the adipocyte to be a geometrical sphere). 
Table 6

Chemical composition and weight of empty body in rats (mean \pm SD) at the end of experiment

\begin{tabular}{|c|c|c|c|c|c|}
\hline Treatment & EBW, g & $\mathrm{DM}, \%$ & Ash, $\%$ & $\mathrm{EE}, \%$ & $\mathrm{CP}, \%$ \\
\hline PFD & $48.03^{\mathrm{a}}$ & $29.17^{\mathrm{a}}$ & $4.39^{\mathrm{a}}$ & $6.12^{\mathrm{a}}$ & $17.03^{\mathrm{a}}$ \\
\hline \pm & 1.49 & 0.94 & 0.20 & 1.01 & 0.35 \\
\hline $10 \mathrm{CP}$ & $109.60^{\mathrm{b}}$ & $33.14^{\mathrm{b}}$ & $3.42^{\mathrm{b}}$ & $11.93^{b}$ & $15.69^{b}$ \\
\hline \pm & 17.99 & 1.32 & 0.33 & 1.74 & 0.65 \\
\hline $10 \mathrm{CP}+\mathrm{Cr}$ & $122.90^{\mathrm{c}}$ & $35.93^{\mathrm{b}}$ & $3.07^{\mathrm{b}}$ & $15.77^{\mathrm{c}}$ & $15.19^{\mathrm{b}}$ \\
\hline \pm & 21.14 & 1.23 & 0.45 & 1.89 & 0.75 \\
\hline $10 \mathrm{CP}+\mathrm{CARN}$ & $111.67^{\mathrm{b}}$ & $34.40^{\mathrm{b}}$ & $3.15^{\mathrm{b}}$ & $13.44^{\mathrm{b}}$ & $15.44^{\mathrm{b}}$ \\
\hline \pm & 15.88 & 2.33 & 0.36 & 3.04 & 0.48 \\
\hline $20 \mathrm{CP}$ & $140.68^{d}$ & $29.74^{\mathrm{a}}$ & $3.19^{\mathrm{b}}$ & $8.00^{\mathrm{d}}$ & $16.87^{b}$ \\
\hline \pm & 10.92 & 1.73 & 0.21 & 2.17 & 0.52 \\
\hline $20 \mathrm{CP}+\mathrm{Cr}$ & $146.85^{\mathrm{d}}$ & $31.88^{\mathrm{a}}$ & $3.07^{\mathrm{b}}$ & $9.90^{\mathrm{d}}$ & $16.98^{\mathrm{b}}$ \\
\hline \pm & 5.25 & 2.08 & 0.17 & 1.95 & 0.14 \\
\hline $20 \mathrm{CP}+\mathrm{CARN}$ & $144.50^{\mathrm{d}}$ & $30.22^{\mathrm{a}}$ & $3.37^{\mathrm{b}}$ & $8.17^{\mathrm{d}}$ & $16.86^{\mathrm{b}}$ \\
\hline \pm & 11.83 & 0.58 & 0.36 & 0.66 & 0.51 \\
\hline
\end{tabular}

$\mathrm{SD}=$ standard deviation; $\mathrm{EBW}=$ empty body weight; $\mathrm{DM}=$ dry matter; $\mathrm{EE}=$ ether extract; $\mathrm{CP}=$ crude protein $(\mathrm{N} \times 6.25)$; Values in a column with different letters in superscript $(\mathrm{a}, \mathrm{b}, \mathrm{c}, \mathrm{d})$ are significantly different at $\mathrm{P}<0.05$

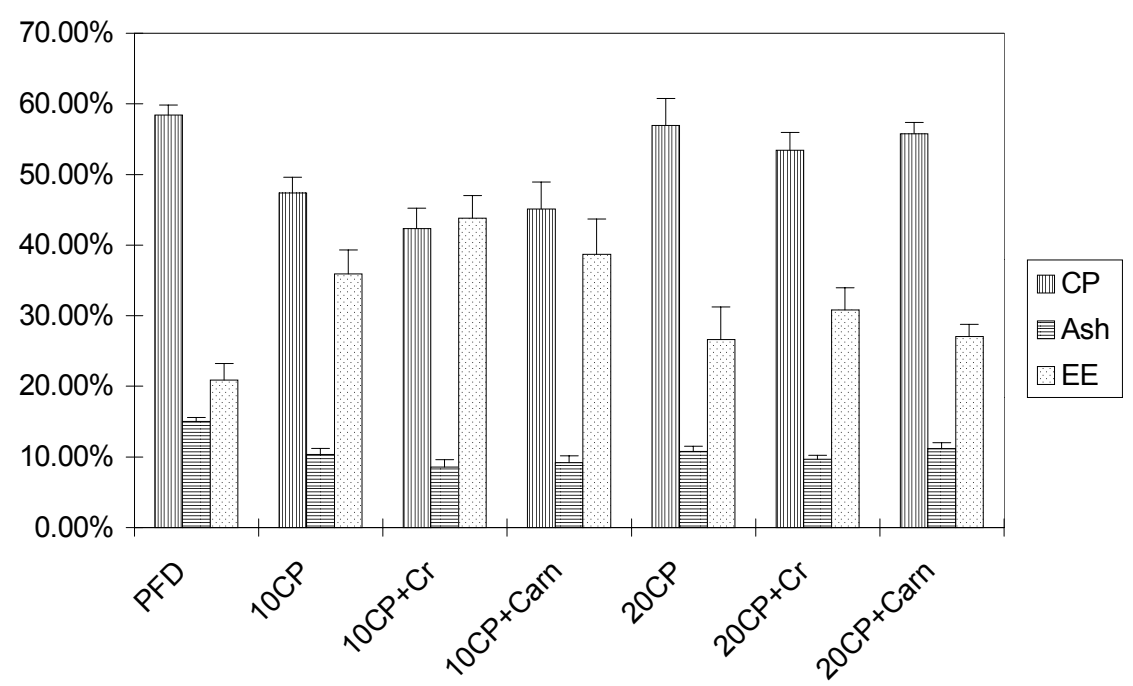

Fig. 1. Chemical components of dry matter of rat bodies at the end of the trial, \% (mean \pm SD). For abbreviations see Table 2 
Table 7

Epididymal fat weight, adipocyte surface and TOBEC number ('E') at the end of the trial $($ mean $\pm \mathrm{SD} ; \mathrm{n}=6)$

\begin{tabular}{lccc}
\hline \multicolumn{1}{c}{ Treatment } & Epididymal fat, g & Adipocyte surface, $\mu \mathrm{m}^{2}$ & 'E' number \\
\hline PFD & $0.13 \pm 0.03^{\mathrm{a}}$ & $1780 \pm 217^{\mathrm{a}}$ & $25.6 \pm 2.8^{\mathrm{a}}$ \\
\hline $10 \mathrm{CP}$ & $0.72 \pm 0.12^{\mathrm{b}}$ & $2872 \pm 143^{\mathrm{b}}$ & $61.0 \pm 9.1^{\mathrm{b}}$ \\
$10 \mathrm{CP}+\mathrm{Cr}$ & $1.16 \pm 0.41^{\mathrm{d}}$ & $3592 \pm 551^{\mathrm{c}}$ & $79.5 \pm 16.6^{\mathrm{c}}$ \\
$10 \mathrm{CP}-\mathrm{CARN}$ & $0.78 \pm 0.20^{\mathrm{b}}$ & $3264 \pm 503^{\mathrm{c}}$ & $72.3 \pm 17.8^{\mathrm{c}}$ \\
\hline $20 \mathrm{CP}$ & $0.67 \pm 0.14^{\mathrm{b}}$ & $2694 \pm 354^{\mathrm{b}}$ & $112.1 \pm 15.3^{\mathrm{d}}$ \\
$20 \mathrm{CP}+\mathrm{Cr}$ & $0.94 \pm 0.27^{\mathrm{c}}$ & $3113 \pm 484^{\mathrm{c}}$ & $128.8 \pm 14.7^{\mathrm{e}}$ \\
CP+CARN & $0.64 \pm 0.12^{\mathrm{b}}$ & $2631 \pm 322^{\mathrm{b}}$ & $110.6 \pm 22.2^{\mathrm{s}}$ \\
\hline
\end{tabular}

For symbols see Table 2. Values in a column with different letters in superscript (a, b, c, d, e) are significantly different at $\mathrm{P}<0.05$

\section{Table 8}

Total fat and protein produced per an average rat during the 15-day test period with the calculated average adipocyte diameter ${ }^{*}$

\begin{tabular}{lccccc}
\hline \multicolumn{1}{c}{ Treatment } & Fat, grams & $\%$ & Protein, grams & $\%$ & $\begin{array}{c}\text { Adipocyte } \\
\text { diameter, } \mu \mathrm{m}\end{array}$ \\
\hline PFD & 2.93 & $22.40 / 26.04^{* *}$ & 8.18 & $47.56 / 34.47$ & 47.6 \\
\hline $10 \mathrm{CP}$ & 13.08 & 100.00 & 17.20 & 100.00 & 60.5 \\
10CP+Cr & 19.38 & 148.17 & 18.67 & 108.55 & 67.6 \\
10CP+CARN & 15.00 & 114.68 & 17.24 & 100.23 & 64.5 \\
\hline 20CP & 11.25 & 100.00 & 23.73 & 100.00 & 58.6 \\
20CP+Cr & 14.54 & 129.24 & 24.94 & 105.10 & 63.0 \\
20CP+CARN & 11.81 & 104.98 & 24.36 & 102.65 & 57.9 \\
\hline
\end{tabular}

*Derived values, no standard deviation can be given; ${ }^{* *}$ compared to the two control diets (10CP and 20CP). For symbols see Table 2

\section{Discussion}

The purpose of this study was to determine changes in the chemical composition of the total body of rats fed protein-free diet or 10 or $20 \%$ CP containing diets supplemented or not supplemented with chromium nicotinate or Lcarnitine. In addition, the accuracy of other estimating methods like the measurement of epididymal fat pad weight, adipocyte surface and total body electrical conductivity, was evaluated and compared. The latter two are non-invasive and can be carried out in live animals, which holds animal welfare concerns, too. 
Comparing the protein-free, low- and high-protein diets, it can be established that the feed intake increased parallel to the protein level. Our results show that organic chromium was the most effective in improving both fat and protein accretion (Table 8). There was some apparent protein retention even on the protein-free diet. This is due at least to three factors: (1) Rats kept on a protein-free diet (like those in the present study) or during starvation lose weight (Uezu et al., 1983), especially fat and water. Consequently, the protein content of the whole body and that of the dry matter are higher (Kleiber, 1987), but the absolute value will decrease. (2) Restricted fed rats tend to show a high level of coprophagy (Williams and Senior, 1985), which, in turn, may improve the nitrogen supply. (3) The liver function can contribute by synthesising non-essential amino acids.

The above finding is valid at both CP levels. On a marginal protein supply the relative effect is even more expressed. At low (10\%) CP level L-carnitine is able to induce a moderate fat accumulation but has no effect on protein retention. In contrast, at optimum protein provision L-carnitine induces a moderate improvement both in fat and protein accretion. It is interesting to give the crude protein levels as percentage of the dry matter: 58.38 (PFD), 47.34 (10CP), 42.28 $(10 \mathrm{CP}+\mathrm{Cr}), 41.68(10 \mathrm{CP}+\mathrm{CARN}), 56.72(20 \mathrm{CP}), 53.26(20 \mathrm{CP}+\mathrm{Cr})$ and 55.79 $(20 \mathrm{CP}+\mathrm{CARN})$. This means that, calculated in dry matter content, absolute protein intake has more decisive effect than do the additives.

The calculated adipocyte diameters (between 47.6-67.6 $\mu \mathrm{m}$ ) follow a similar tendency as does the total fat mass, which suggests the validity of the cellularity concept (Robelin and Casteilla, 1990).

Protein utilisation, expressed in PER and NPR values, is relatively better at a marginal protein supply. This shows the adaptation of the organism, which may have great practical implications for animal production. On the other hand, the increasing CP intake 'itself' improved protein retention and decreased the fat accretion. This phenomenon may be advantageous for the consumers, because the rat is considered as a good model for the fattening pig. The following actual correlations have been found: $\mathrm{y}_{1}=4.21 \mathrm{x}_{1}+8.70(\mathrm{r}=+0.81)$ and $\mathrm{y}_{2}=17.36 \mathrm{x}_{1}-$ $1.48(\mathrm{r}=-0.58 ; \mathrm{P}<0.05)$, and $\mathrm{y}_{1}=-4.54 \mathrm{x}_{2}+0.005(\mathrm{r}=+0.89 ; \mathrm{P}<0.01)$, where $\mathrm{y}_{1}=$ fat content of EBW, $\mathrm{y}_{2}=$ the protein content of EBW, $g ; \mathrm{x}_{1}=$ weight of epididymal fat pad, $g$; and $\mathrm{x}_{2}=$ adipocyte surface, $\mu \mathrm{m}^{2}(\mathrm{n}=42)$. There was no significant difference between the fat percentage and TOBEC number $(r=0.01 ; \mathrm{P}>$ $0.05)$, as well as the fat amount and the ' $E$ ' number $(\mathrm{r}=+0.17)$.

The great individual differences may explain the inconsistency of the TOBEC data (Amount et al., 1994; Fekete et al., 1996b; Milisits et al., 2000). The repeatability of this method can be assured only by a previous deprivation of feed and water, which is not allowed by the current animal welfare regulations.

Summarising our present findings, the amount of the epididymal fat pad seems to be a good indicator of total body fatness in rats. Adipocyte morphome- 
try and total body conductivity can be considered methods which are good only at the population level.

\section{General conclusions}

The overall effect of L-carnitine used as a feed additive is relatively small, but the effect is more selective and enhances mostly the decreased fat deposition. Organic chromium has greater impact on the general breeding parameters (liveweight, feed intake) and significantly increases both fat and protein accretion. There is an interaction between protein level and repartitioning agents (nutriceuticals): at a low CP level, L-carnitine was practically ineffective in improving protein synthesis and inhibiting fat deposition. On the other hand, chromium nicotinate is effective both at marginal and at optimum protein supply, but in the first case fat accumulation is more expressed. The authors hypothesise that the effect of organic (trivalent) chromium may be explained by the strong feed intake increasing stimulus, which should derive from the blood glucose diminishing effect by better functioning of the glucose tolerance factor (GTF), i.e. having an insulin-like feature (NRC, 1997).

\section{Acknowledgements}

The authors thank the Hungarian Scientific Research Fund (OTKA T26606), the Ministry of Education (FKFP 0644/97) and the Szent István University, Faculty of Veterinary Science Budapest (NKB-002) for the financial support of this study.

\section{References}

A.O.A.C. (1980): Official Methods of Analysis. 15th ed. Association of Official Analytical Chemists, Washington, D. C.

Amount, G., Poisot, F., Saminadin, G., Borel, H. and Alexandre, G. (1994): Body condition score and adipose cell size determination for in vivo assessment of body composition and postmortem predictors of carcass components of Creole-goat. Small Ruminant Res. 15, 77-85.

Barker, D. L. and Sell, J. L. (1994): Dietary carnitine did not influence performance and carcass composition of broiler chickens and young turkeys fed low- or high-fat diets. Poult. Sci. 73, 281-287.

Bell, R. C., Lanou, A. J., Frongillo, E. A. Jr., Levitsky, D. A. and Campbell, T. C. (1994): Accuracy and reliability of total body electrical conductivity (TOBEC) for determining body composition of rats in experimental studies. Physiol. Behav. 56, 767-773.

Borum, P. R. (1983): Carnitine. Ann. Rev. Nutr. 3, 233-259.

Clouet, P., Sempore, G., Tsoko, M., Gresti, J., Demarquoy, J., Niot, I., Bezard, J., Martin-Privat, P. (1996): Effect of short- and long-term treatments by a low level of dietary L-carnitine on parameters related to fatty acid oxidation in Wistar rat. Biochim. Biophys. Acta 1299, 191-197.

EM-SCAN Inc. (1991): Model SA-2 Small Research Animal Body Composition Analyzer Operation Manual. Springfield, IL. 
Fekete, S. (1992): The rabbit body composition: Methods of measurement, significance of its knowledge and the obtained results. A critical review. J. Appl. Rabbit Res. 15, 72-85.

Fekete, S. and Brown, D. L. (1993): The major chemical components of the rabbit whole body measured by direct chemical analysis, deuterium oxide dilution and total body electrical conductivity. J. Vet. Nutr. 2, 23-29.

Fekete, S. and Kósa, E. (1999): Dietary effects of organic chromium in growing pigs: review and preliminary publication (in Hungarian, with English abstract). Magyar Állatorvosok Lapja 121, 29-34.

Fekete, S., Huszenicza, G., Kellems, R. O., Szakáll, I., Fébel, H., Husvéth, F., Nagy, P., Kulcsár, M., Kósa, E., Gaál, T., Rudas, P. and Oppel, K. (1996a): Influence of deficient intake of high and low degradable protein on body composition, metabolic adaptation, production and reproductive performance in early lactation dairy cows. Acta Vet. Hung. 44, 309-333.

Fekete, S., Kósa, E. and Pucsok, A. (1999): A study of the effect of yeast and Cr-yeast on fattening pigs (in Hungarian). Állattenyésztés és Takarmányozás 48, 553-557.

Fekete, S., Szakáll, I., Andrásofszky, E., Kósa, E. and Hullár, I. (1996b): Body composition of mice of different condition score and sex. Acta Vet. Hung. 44, 399-410.

Fiorotto, M. L., Cochran, W. J., Funk, R. C., Sheng, H. P. and Klish, W. J. (1987): Total body electrical conductivity measurements: effects of body composition and geometry. Am. J. Physiol. 252, R794-R800.

Forbes, G. B. (1987): Human Body Composition. Growth, Aging, Nutrition, and Activity. Springer Verlag, New York, Berlin, Heidelberg, London, Paris, Tokyo. pp. 61-62.

Gálvez, J. F., Baumgartner, M., Daza, A. and Gutiérrez-Barquin, M. G. (1996): L-carnitine boosts piglet growth. Feed Mix. 4, $26-29$.

Guggenbuhl, P. (1996): Evaluation of beta2-adrenergic agonists repartitioning effects in the rat by non-destructive method. J. Anim. Physiol. A. Anim. Nutr. 75, 31-39.

Hegedűs, M., Kralovánszky, U. P. and Mátrai, T. (1981): Evaluation of Feed Proteins (in Hungarian). Mezőgazdasági Kiadó, Budapest.

Hemel-Grooten, van den H. N., Garssen, G. J., Schreurs, V. V. A. M., Peijnenburg, H. C. M. and Verstegen, M. W. A. (1998): Chemical composition of body compartments and plasma parameters after protein-free feeding and realimentation in growing pigs. J. Anim. Physiol. A. Anim. Nutr. 79, 162-173.

Hirsch, J. and Gallian, E. (1968): Methods for the determination of adipose cell size in man and animals. J. Lipid Res. 9, 110-119.

Hirsch, J. and Han, P. W. (1969): Cellularity of rat adipose tissue: effect of growth, starvation, and obesity. J. Lipid Res. 10, 77-82.

Hirsch, J. and Knittle, J. L. (1970): Cellularity of obese and nonobese human adipose tissue. Fed. Proc. 29, 1516-1521.

Houseknecht, K. L., Baile, C. A., Matteri, R. L. and Spurlock, M. E. (1998): The biology of leptin: a review. J. Anim. Sci. 76, 1405-1420.

Janssen, G. P. J. and De Wilde, R. O. (1995): The influence of long term high dose L-carnitine supplementation in racing pigeons on their weight, carcass composition and feeding behaviour. Proc. Soc. Nutr. Physiol. 4, 57.

Kleiber, M. (1987): The Fire of Life: An Introduction to Animal Energetics. Reprinted with corrections. Robert E. Krieger Publishing Co., Inc. Malabar, pp. 41-59.

Kósa, E. and Fekete, S. (1999): Effect of Cytoplex Cr (organic chromium) in fattening pig nutrition (in Hungarian, with English abstract). Magyar Állatorvosok Lapja 121, 674-676.

Kósa, E., Drén, A. C. and Fekete, S. (1997): Measurement of dwarf and New Zealand White suckling rabbits' body composition by TOBEC method. Preliminary publication (in Hungarian). Állattenyésztés és Takarmányozás 46, 415-419.

Kovalcsik, G. (1996): EXCEL for Windows 5.0. ComputerBooks. Budapest. 
Milisits, G., Szendrő, Zs., Mihálovics, Gy., Bíró-Németh, E., Radnai, I. and Lévai, A. (2000):Use of the TOBEC method for predicting the body composition of growing rabbits. Proc. 7th World Rabbit Congress (ISSN 1257-5011) A, pp. 637-642.

Mowat, D. N. (1997): Organic chromium in animal nutrition. Chromium Books. Guelph, Ontario. NRC (1997): The role of chromium in animal nutrition. National Research Council. Washington, D. C.

Owen, K. Q., Weeden, J. L., Nelssen, J. L., Blum, S. A and Goodband, R. D. (1993): Effect of Lcarnitine and addition on performance and carcass characteristics of growing-finishing swine. J. Anim. Sci. 71 (Suppl. 1) 62.

Rabie, M. H. and Szilágyi, M. (1998): Effects of L-carnitine supplementation of diets differing in energy levels on performance, abdominal fat content, and yield and composition of edible meat of broilers. Br. J. Nutr. 80, 391-400.

Robelin, J. and Casteilla, L. (1990): Differentiation: growth and development of adipose tissues. INRA Prod. Anim. 3, 342-352.

Sainz, R. D. and Wolff, J. E. (1988): Effects of the $\beta-2$ agonist, cimaterol, on growth, body composition and energy expenditure in rats. Br. J. Nutr. 60, 85-90.

Smith, S. B., Prior, R. L., Ferrell, C. L. and Mersmann, H. J. (1984): Interrelationship among diet, age, fat deposition and lipid metabolism in growing steers. J. Nutr. 114, 153-162.

SPSS Inc. (1989-1995): SPSS for Windows 06.01.04. Version.

Steele, R. G. D. and Torrie, H. (1980): Principles and Procedures of Statistics. A biometrical approach. 2nd edition. McGraw-Hill Book Co. Inc. New York, NY.

Stenger, J. and Bielajew, C. (1995): Comparison of TOBEC-derived total body fat with fat pad weights. Physiol. Behav. 57, 319-323.

Szakáll, I., Beynen, A. C., Lemmens, I., Andrásofszky, E. and Fekete, S. (2000): Alteration of body composition in rats. Effect of inorganic chromium, manganese and DL-carnitine. In: Szakáll, I. (2000): Investigation of body composition in broiler chickens and laboratory rodents. PhD Thesis. Szent István University, Faculty of Veterinary Science, Budapest.

Tilley, J. (1995): Chromium improves carcasses. Pig Intern. 25, 23-24.

Trocki, O., Baer, D. J. and Castonguay, T. W. (1995): An evaluation of the use of total body electrical conductivity for the estimation of body composition in adult rats: effect of dietary obesity and adrenalectomy. Physiol. Behav. 57, 765-772.

Uezu, N., Yamamoto, S., Rikumari, T., Kishi, K. and Inoue, G. (1983): Contribution of individual body tissues to nitrogen excretion in adult rats fed protein-deficient diets. J. Nutr. 113, $105-114$.

Williams, V. J. and Senior, W. (1985): The effect of coprophagy in the adult rat on rate of passage of digesta and on digestibility of food fed ad libitum and in restricted amounts. J. Nutr. 115, $1147-1153$. 